ADDIN, Volume 10, Number 2, August 2016

\title{
DEVELOP QUALITY PEOPLE THROUGH DA'WAH IN THE FACE OF THE ASEAN ECONOMIC COMMUNITY (AEC)
}

Mubasyaroh

STAIN Kudus, Central Java, Indonesia

mubasyarob@gmail.com

\begin{abstract}
Recent decades, we often hear the advent of the Asean Economic Community (AEC) which is a community that is struggling in the field of free market economies in particular, so it requires some readiness; economic, capital, and the equally important need readiness of human resources as the party who run the economy. For Indonesia alone, ME $A$ will be an opportunity for trade barriers will tend to diminish even be non-existent. This will impact on increasing exports, which in turn will increase the GDP of Indonesia. On the other hand, the Muslims as the vast majority of Indonesia's population must face the Asean Economic Community (AEC). In this case Indonesian Muslims should be careful and ready to face the AEC. Campaigners Indonesian economy began to prepare for the era of free markets that will be enforced. The era of the free market itself is the result of the formation of the Asean Economic Community (AEC). The free market itself covering the areas of capital, goods and services, and labor. In this regard, please note that the mission is a process conducted by a conscious and planned to invite the people to the path of Allah, to improve the situation for the better (da'wah is the promotion and development) in order to achieve certain goals, namely
\end{abstract}


.Mubasyaroh

to live happily in the world hereafter. In this paper will attempt to peel da'wah efforts in developing the quality of the people in the face of the Asean Economic Community (AEC).

Keywords: AEC, Da'wah, Develop Quality People.

\section{Abstrak}

Beberapa dekade terakhir, kita sering mendengar istilah Masyarakat Ekonomi Asean (AEC) yang merupakan komunitas yang bergerak khususnya di bidang ekonomi pasar bebas, sebingga memerlukan beberapa kesiapan; ekonomi, modal, dan kesiapan sumber daya manusia sebagai pihak yang menjalankan ekonomi. Untuk Indonesia sendiri, ME $A$ akan menjadi kesempatan bagi pelaku perdagangan. Hal ini akan berdampak pada peningkatan ekspor, yang nantinya akan meningkatkan pendapatan Indonesia. Di sisi lain, umat Islam sebagai penduduk mayoritas Indonesia harus menghadapi Masyarakat Ekonomi Asean (MEA). Dalam hal ini umat Islam Indonesia harus berhatihati dan siap menghadapi MEA. Masyarakat ekonomi Indonesia mulai mempersiapkan era pasar bebas yang akan diberlakukan. Era pasar bebas itu sendiri merupakan hasil dari pembentukan Masyarakat Ekonomi Asean (MEA). Pasar bebas itu sendiri meliputi bidang modal, barang dan jasa, dan tenaga kerja. Dalam hal ini, perlu diketahui bahwa misi adalah suatu proses yang dilakukan secara sadar dan terencana untuk mengajak masyarakat ke jalan Allah, untuk memperbaiki situasi menjadi lebih baik (dakwah adalah promosi dan pengembangan) untuk mencapai tujuan tertentu, yaitu untuk bidup bahagia di dunia dan di akbirat. Tulisan ini akan mencoba untuk mengupas upaya dakwah dalam mengembangkan kualitas masyarakat dalam menghadapi Masyarakat Ekonomi Asean (MEA).

Kata Kunci: MEA, Dakwah, Pengembangan Kualitas Masyarakat.

\section{A. Introduction}

AEC (Asean Economic Community) is a term that lately raised in line with the emergence of a free market in the Asian region, so this will have an impact on the activities 
of community economies, as well as a challenge for Muslims to further advance its economy. It seems to be a fairness, in order to survive, must Berechiah hard. As we understand together that the AEC has a pattern of economic integration of ASEAN by establishing a system of free trade or free trade between member countries of ASEAN. The members of ASEAN, including Indonesia has concluded an agreement of the ASEAN Economic Community. AEC is a term that is present in Indonesia, but basically the MEA same as the AEC or the ASEAN Economic Community.

There are some things that need to be prepared to welcome the presence of the AEC good preparation in terms of economic and human resources (resource people) in order to suck in facing the Asian Economic Community (AEC) is. The essential thing is set up according to the author resource people, as this will affect economic conditions of society itself. There are some activities that can be done in preparing human resources (the people) of them is through the da'wah of Islam.

As we know that the Islamic da'wah is the cornerstone of religious teaching, because with preaching religious teachings be preserved and not lost. Because of the importance of propaganda for the sustainability of the teachings of religion then it is an important concern to be able to know the procedures for effective propaganda so that propaganda can be accepted in all aspects of society.

Hence the inclusion of various teachings or not relevant to the understanding of religious values, there is a tendency to make religion to be helpless and more so when religion is no longer used as a way of life of Islam in various fields. It may also hit the Muslims when religion no longer function effectively in the collective life. Of course, this situation can effect if religion fails to give a true alternative civilization and prosecuted by any social change. Besides, when the Muslim community serves as 
a community established on the joints of moral faith, Islam and piety, and can be realized and understood as a whole and coherent is a community that is not exclusive because it acts as an "al-Umma al-Wasatan" is as exemplary in the middle of the flow of life which is too complex, full of dynamic changes, challenges and choices that are sometimes very dilemma.

In the development and modernity gives a too high appreciation of the material. The implication is the power of faith that had owned the more degraded. The climax is the fact that hit most Muslims are increasingly terejat by a spiritual void. Especially in the face of any changes in the social environment, including challenges to the height of the Asian Economic Community (AEC).

AEC is expected to realize the achievement of an area is stable, prosperous and highly competitive with balanced economic growth and reduced poverty and socioeconomic gap.

See the above phenomenon, of course, Muslims hit by concerns that could undermine the morale of faith so we must find the best solution desired by Islam to carry out da'wah effectively to develop the resource capacity of Muslims to effectively and efficiently on an ongoing basis.

As one of the efforts in providing Islamic solutions to the problems of life, the Sheykh al-Babiy al-Khuli call da'wah ${ }^{1}$ as "an attempt to move the human situation to a better situation". The transfer of this situation covers all aspects of human life. Displacement of the situation to the situation of scientific ignorance, of a situation of poverty to a decent life situaso, from situation to situation retardation of progress. Da'wah touch effort how to create the life of a prosperous, secure and peaceful to develop individual creativity and community.

\section{p. 27.}

\footnotetext{
${ }^{1}$ Al-Babiy al-Khuli, Tazkirah ad-Du'ab (Mesir: Dar al-Kitab al-'Arabi, 1952),
} 
Da'wah is essentially an effort to empower and increase a better state of the traffic system. In this case that would be the focus is improving the quality of the people.

\section{B. Discussion}

\section{Conception of Da'wah}

In terms of propaganda language is Arabic دعا- يدعو -دعوة proselytizing which means to call, invite, ask, ask, beg, embed, have come, encourage, lead, bring, pray, weeping, and wailing. ${ }^{2}$

While the terms of the terminology, so many different opinions about the definition of proselytizing among experts, among others:

a. According to A. Hasmy in his Dustur Propagation According to the Koran, defines propaganda namely: to persuade others to believe and practice the Islamic faith and the Shari'a first been believed and practiced by the preachers themselves. ${ }^{3}$

b. According to Sheikh Ali Mahfud. Islamic Propagation is to motivate people to do good according to the instructions, told them to do good and forbid them to do kemungkaran, so they get happiness in this world and hereafter. ${ }^{4}$

c. Amrullah Ahmad, ${ }^{5}$ found, propagation of Islam is the actualization, imani (theological) which is manifested in a system of human activities in the field of social faithful conducted regularly to affect the ways of feeling, thinking, acting, and acting human being on the level of

${ }^{2}$ Ahmad Warson Munawwar, al-Munawnir Kamus Arab-Indonesia (Surabaya: Pustaka Progresif, 1997).

${ }^{3}$ A. Hasymi, Dustur Dakwah Menurut al-Qur'an (Jakarta: Bulan Bintang, 1997), p. 18.

${ }^{4}$ Syekh Ali Mahfudz, Hidayah al-Mursyidin ila Turuq al-Wa'az, wa al-Khitabah (Beirut: Dar-al Ma'rifah, t.t.), p. 14.

${ }^{5}$ Amrullah Ahmad, Dakwah Islam dan Perubahan Sosial: Suatu Kerangka Pendekatan dan Permasalahan (Yogyakarta: Bina Putra, 1993), p. 2. 
activity individual and socio-cultural in order to authorize the establishment of Islam in all aspects of life in a certain way.

On the other hand Asmuni Syukur Thanks be argued that the mission is an activity or process conducted by a conscious and planned to invite the people to the path of Allah, to improve the situation for the better (da'wah is the promotion and development) in order to achieve certain goals, namely to live happily in the world hereafter. ${ }^{6}$

Meanwhile, according to B.J. Boland," found "...that da'wah meant the propagandation of Islam not only by precabing da'wah publication, but also by deeds and acitivities in all areas of social life, in other words that da'wah had to be comprehensive islamization of society".

Thus some good da'wah definitions and terminology according to the etymological meaning, all point to the activities aimed at the positive in people. Positive change is manifested by an increase in faith. If the definition of propaganda is associated with some phenomenon of da'wah, then can stated that the mission is a process of increasing faith in human beings in accordance Islamic law that "the process" shows that continuous activity, continuous and gradual. Such improvements to the quality of positive changes: from bad to good, or from good to better.

Some of the terms associated with the delivery of the missionary activity is:

a. Tabligh, as Amrullah Ahmad, ${ }^{8}$ argued that the sermons are part of a system of Islam. Missionary activities as a joint effort merealisaikan those who believe in the 1983), p. 21.

${ }^{6}$ Asmuni Syukur, Dasar-dasar Strategi Dakwah Islam (Surabaya: al-Ikhlas,

${ }^{7}$ A. Ilyas Ismail, Paradigmma Dakwah Sayyid Quthub Rekonstruksi Pemikiran Dakwah Harakah (Jakarta: Penamadani, 2006), p. 9.

${ }^{8}$ Amrullah Ahmad, Dakwah Islam dan Perubahan Sosial, p. 49. 
teachings of Islam in all aspects of life are conducted through institutions or organizations. While sermons is an attempt to convey and broadcast the message of Islam carried out by individuals or groups either Lesan and written. It is appropriate in the Q.S. al-Ma'idah [5]: 67.

b. Advice, an activity conveying a greeting to others to correct deficiencies or erroneous behavior ${ }^{9}$ advice more curative and corrective to the condition of a person's religious or poor communities. Advice can also be done through verbal or written. In the context of da'wah, advice is more personal, private and four eyes. The advice is the counseling that solve and overcome one's religius. Because each person has a different problem from one another, then the adviser must be keen in seeing the condition of his client. Giver of advice must be able to feel perceived by the client.

c. Tabsyir and tandzir. Both terms relate to each other: that of bringing religious description of the contents of the warning or threat and the good news or ganjaran. Tabsyir is a description of religious activity that the contents of encouraging news, as news of the promise of God in the form of reward or a haven for those who do righteous deeds. As is the provision of news tandzir warning or a threat to those who violated Islamic shariah or giving bad news. Needs to be seen that the Koran says tabsyir and tandzir always called in tandem that said tabsyir always take precedence. This shows that tabsyir shall take precedence and precedence of the word tandzir.

Besides some of the terms associated with such propaganda, there is a positive activity that is very close to the core of missionary activity that is meaningful amar ma'ruf nabi munkar ordered to goodness and prevent or prohibit evils. It

\footnotetext{
${ }^{9}$ Ali Aziz, Ilmu Dakwah (Jakarta: Prenada Media Group, 2009), p. 23.
} 
is an obligation for every Muslim as well as the identity of the believer. Among jurisprudents amar ma'ruf nabi munkar known as al-hisbah an activity ordered kindness when there are leaves her with blatant and prohibit misguidance when there appears to be doing it. ${ }^{10}$ In this regard Imam Ghazali also many call hisbah when explaining about amar ma'ruf nabi munkar. In the context of da'wah, amar ma'ruf can be implemented in two forms, first, the da'wah in ways that smooth, soft, non-coercive and non-violence, it is often referred to as cultural propaganda and secondly, is al-hisbah that emphasizes power approach. Alhisbah can walk when state power is in the hands of Muslims and implement the Islamic law that legally.

Thus, the way al-hisbah strictly comparable to tathawuk who encourage others to do good and encourage to leave misguidance. Fields al-hisbah is the obligation or the rights of others to be met, while tatawuk regarding matters that are the recommended (sunnah).

From some of the da'wah discourse, it is known that the mission is an active process, persuasive, and comprehensive. Thus preachers have to find someone as $\mathrm{mad}^{\prime} u$ or propaganda goals by providing persuasion and led her to the path of Allah.

Thus, in practice proselytizing can be implemented using several methods including:

a. Method lecture;

b. Method of discussion;

c. Method counseling;

d. The method of writing;

e. The method of empowerment;

f. The method of institutional.

${ }^{10}$ Abdul Karim Zaidan, Usul ad-Da'wah (Beirut: Mu'assasah arRisalah,1993), p. 174. 
Keep in mind that the methods da'wah is not something that is final. And in practice a preacher can use several methods simultaneously known by the variety of methods of propaganda. So the propaganda that do not monotonous and will attract attention $\operatorname{mad}^{\prime} u /$ receiver da'wah.

Each activity must have a goal, as well as with the activities carried out propaganda that aims to have a positive effect, namely a change in attitude and behavior on self mad' $u$. According to Majdi Hilali, ${ }^{11}$ any behavioral changes experienced three stages namely reason, the beliefs about an action, such as voice or whisper hearts fun, and lust embodied by the members of the body in the form of real action.

Da'wah is always directed to affect the three aspects of change in mad' $^{\prime} u$ are aspects of knowledge, aspects of attitude and aspects of behavior. In line with this Jalaluddin Rahmat ${ }^{12}$ states that there are three changes in behavior; cognitive effects, related to changes in what is known, understood or perceived audience. This effect is related to the transmission of knowledge, skills, confidence and information. Affective effect, this effect arises when a change in what is perceived, liked or hated audience that includes everything related to attitudes, emotions and values. The latter effect is a behavioral effect, which refers to the actual behavior that can be observed, which include patterns of action, activity, or behavioral habits.

In this case, Severin and Tankarl Jr. ${ }^{13}$ argued that the attitude expected of the persuasion process is basically our tendency toward an object or taste like or dislike towards these objects. Attitude is also a belief or statements considered true

${ }^{11}$ Majdi Hilali, Mengubah Hal-hal Negatif dalam Diri Jakarta: Samara Publishing, 2008), p. 47.

${ }_{12}$ Jalaluddin Rahmat, Psikologi Agama Sebuah Pengantar (Bandung: Mizan Pustaka, 2005), p. 269.

${ }^{13}$ J. Warner Severin and James W. Tankard Jr., Communication Theories: Origins, Methods, and Uses in The Media (Teori Komunikasi) (Jakarta: Prenada Media, 2005), p. 177. 
by someone. Attitudes have three components: affective (a or feelings toward an object), a cognitive component (conviction against an object), and behavior (actions of an object).

Based on the above behavior change process, it needs to be seen is about acceptance of da'wah emphasized to address the extent to which the three aspects of the change, namely cognitive, affective and behavioral mad' $u$ (recipient of the da'wah).

\section{ASEAN Economic Community (AEC)}

ASEAN Economic Community (AEC) is a form of economic integration of ASEAN in free trade system freely between ASEAN countries. MEA is a community of ASEAN (ASEAN Community) in Economics or ASEAN Economic Community (AEC) which was endorsed at the Summit (Summit) ASEAN 9th in Bali in 2003, otherwise known as Bali Concord II. The community building initiated by the Heads of State of ASEAN after the 1997 economic crisis in Southeast Asia. ${ }^{14}$

ASEAN Economic Community (AEC) is a unification efforts and the strengthening of economic cooperation into the gates of success and increasing prosperity of the ASEAN countries. ASEAN Economic Community (AEC) will be the goal of regional economic integration by 2015 . The member countries envisage that the AEC will have the following key characteristics: (a) a single market and production base (b) a highly competitive economic region, (c) region of equitable economic development, and (d) the area is fully integrated into the global economy. Related to that, each member state will increase the concentration (focus) on how to position itself among the other member states.

${ }^{14}$ Ana Syukriah, "Peningkatan Eksistensi UMKM Melalui Comparative Advantage Salam Rangka Menghadapi MEA 2015 di Temanggung”, Universitas Negeri Semarang, 2013, p. 45. 
More than a decade ago, ASEAN leaders agreed to establish a single market in Southeast Asia. This was done in order to increase the competitiveness of ASEAN as well as China and India could compete to attract foreign investment. Foreign investment in the region is needed to boost employment and improve welfare. The formation of a single market which is termed the Asean Economic Community (AEC) This will allow the country to sell goods and services easily to other countries across Southeast Asia so the competition will be intense.

Not to mention the impact of competitive local products and imports. With a much larger capital, and mastery of advanced technology plus state alignments, then big countries can produce far more goods, which consequently can result in lower selling prices. While people generally prefer to buy products cheaper despite imports, so slowly that local entrepreneurs will be many out of business because of lost competitiveness. More dangerous if a foreign corporation can get in control of vital sectors of the country because of the power of big capital, the common ownership of goods such as oil, natural gas, and other minerals, as well as springs and forests will be theirs. People will lose their rights, while the government can not intervene. The state's role as a servant of the people is getting reduced, only serves as a regulator.

There are several consequences of the AEC. The consequences of the free flow of goods and services, free flow of investment, the flow of skilled labor, as well as the free flow of capital. To deal with the effects of it, Indonesia still has obstacles.

First, the quality of education in Indonesia is still low labor force. Recorded until February 2014, the number of junior high school educated workers to bottom as much as 64 percent, or 76.4 million people out of a total of 118 million workers. Second, the smooth flow of goods and services is still weak due to the availability and quality of infrastructure 
is minimal. Third, the local industrial sector fragile due to dependence on imports of raw materials and semi-finished. Fourth, Indonesia is still hampered energy supply constraints. As well as the Fifth, weak Indonesia onslaught of imports.

Based on the above, then Indonesia as part of the ASEAN countries that would be affected by the Asean Economic Community (AEC) had to work hard to prepare all the devices in facing the AEC.

\section{Develop Quality People}

Agenda for the development of the community (ummah) is also in accordance with the intended by Allah as stated in the Q.S. Ali 'Imran [3]: 110. So it can be seen that the contribution of religious values in this propaganda is to improve society, provided that the missionary movement was not simply delivered without evaluated. Examples of this is now in the television Subuh lectures conducted at five o'clock in the morning. Who got up at five o'clock it was only a few people who have strong religious. Sometimes, giving lectures dawn that we already know all. Properly, the religious lectures in spare time. Instead, today's leisure time is mostly filled stories of demons, tuyul stories, and the stories that do not educate the children of the nation.

One method of preaching to the real action is the method of development of the community (ummah) is preaching with efforts to build up power, by encouraging, motivating, and raise awareness of their potential and strive to develop it based process independence. This method is always interconnected between the three actors, namely the community (community), government and agency (preacher). Through linking these three actors, we can formulate the implementation stage. ${ }^{15}$

${ }^{15}$ Ambar Teguh Sulistiyani, Kemitraan dan Model-model Pemberdayaan (Yogyakarta: Gava Media, 2004), p. 123-128. 
Dimensions da'wah that is often overlooked by the preachers and scholars is the issue of community development. Today, Muslims have amounted to more than a billion people who are expected to continue to rise. Many parts of the Muslim world that left behind technologically and economically.

They suffered greatly in meeting their needs every day and very stutter to technological developments. As a result, communication science and religion that information should be easily accessible, because that's the difficulty, making them kept underdeveloped and continues to twit.

To overcome this, of course, needed to work together to alleviate poverty and empower the developmentally. It may manifest in the form of vocational education, employment, prevention of the use of illegal drugs, or training of appropriate technology. The agenda must be immediately executed with the cooperation between Muslim organizations and the government or other institutions. Because, basically, the purpose of the mission is to improve the life of mankind on earth and the hereafter.

In this case the quality of the people should be a priority because it will determine his future, diantanya is da'wah in economics. Da'wah economy is the activity of Muslims who are trying to implement Islamic teachings related to economic processes in order to boost the economy and welfare. Islamic teachings in this category, among others; buying and selling, greeting, musaqah, muzara'ah, charity, donation, sacrifice, and others included in it about the hajj. The Islamic teaching have relevance to the economic da'wah that the aspects of production, distribution, suppliers, utilization of goods and services. Then the economy of Muslims will increase and will ultimately improve the welfare of Muslims.

Looking at the phenomenon now with the emergence of new groups in the field of economy, namely the Asean 
Economic Community (AEC), the changes in society, community development and empowerment is a form of da'wah to be done. According to a hadith the Prophet declared, "Pauperism can lead to kufr." Therefore, to avoid kufr, the poverty that afflicts Muslims should immediately be reduced if not eliminated. Da'wah should emphasize the changes and improvements in the material conditions of society, also through improving the quality of resources umat. With the improvement of these conditions, is expected to prevent the tendency towards kufr or converted for getting economic compensation temptation so they switched faith.

To realize such a society, the human resources to undertake missionary work of Islam in this era of course must also focusing on ethical-emancipatory region. Even more so when capitalism and globalization were very disregard of humanity and justice drove non-stop. Critical-emancipatory consciousness as a manifestation of the earthing verses of the Qur'an and the Sunnah of the Prophet Muhammad by the propagators it should not be interpreted as an antiestablishment movement or non-governmental organizations. To develop the quality of the people, at least it should be emphasized three components that is important.

Moral knowing, moral feeling, and moral action. Moral knowing someone is their ability to distinguish values of noble character and morals despicable and universal values. Includes understand logically and rationally (not dogmatic and doktrinis) the importance of noble character and moral hazard despicable in life. This was done through the introduction of the figure of the Prophet Muhammad. as an exemplary figure of noble character through traditions and his Sunnah. While the moral feeling is intended to foster a sense of love and a sense of need for the values of noble character, so that the growing 
awareness and the desire and the need to assess themselves. ${ }^{16}$ The moral doing is revealing habituation behavior was good and admirable in a person in everyday life.

Based on these three components can be stated that good character should be supported by the knowledge of the good, the desire to do good, and ability to do good deeds. In other words, indicators of human beings who have good personal qualities are those who know the good, have the desire to do good, and real-behaved, which coherently radiates as a result of five if, that is: if the thought, though the liver, sports, though the taste, and if the intention. And this is in accordance with the grand design that was developed by the Ministry of National Education in 2010 in efforts to establish the characters within each individual. ${ }^{17}$

Besides, the quality of the people expected are a people who have a sense of responsibility and independence, namely: (a) the ability to define itself, (b) the ability to take responsibility, (c) human maturity, and (d) the overall conditions that allow people to do his purpose in life. Behavior is based on attitudes, values and mindset of system behavior by means of awareness, not instinctive, but there is the meaning of human freedom which is the object of materia ethics. ${ }^{18}$

Responsibility within the framework of morality is the belief that his actions were good. This was in accordance with the expression of Indonesia, which is to say that the person who did the chaos as people who are not responsible, then the question is that the acts committed by the morally justifiable, considering the act can not be accepted by society. Besides

${ }^{16}$ Abdul Majid and Dian Andayani, Pendidikan Karakter Perspektif Islam (Bandung: Remaja Rosdakaya, 2012), p. 112.

${ }^{17}$ Kementerian Pendidikan Nasional Dirjen Pendidikan Dasar Direktorat Pembinaan Sekolah Menengah Pertama, Panduan Pendidikan Karakter di Sekolah Menengah Pertama (Jakarta: Diknas, 2011), p. 16.

${ }_{18}$ Abudin Nata, Akblak Tasawnf dan Karakter Mulia (Jakarta: RajaGrafindo Persada, 2015), p. 113. 
responsibility is also closely related to conscience or intuition in man who always speaks the truth. Someone had called responsible if it is intuitive actions that can be justified on the conscience and to the community at large.

Besides, the human quality is also determined by depraved to the main act, namely hikmah (wise), syaja'ah (officer or knight), and iffah (keep away from sin and immorality). Three kinds of stem morality arises from fair attitude, the attitude of the middle or balanced in its use of the three potential spiritual contained in man, namely 'aql (reasoning) is centered on the head, gadab (anger), based in the chest, and sex drive, based in the stomach. ${ }^{19}$

Thus the moral core in the end comes down to fairness in using the spiritual potential of human beings.

\section{Develop Quality People through Da'wah Facing Asean Economic Community (AEC)}

Dimensions propaganda that is often overlooked by the preachers and scholars is the issue of community development. Today, Muslims have amounted to more than a billion people who are expected to continue to rise. Many parts of the Muslim world that left behind technologically and economically.

They suffered greatly in meeting their needs every day and very stutter to technological developments. As a result, communication science and religion that information should be easily accessible, because that's the difficulty, making them kept underdeveloped and continues to twit.

To overcome this, of course, needed to work together to alleviate poverty and empower the developmentally. It may manifest in the form of vocational education, employment, prevention of the use of illegal drugs, or training of appropriate technology.

${ }^{19}$ Harun Nasution, Falsafah dan Mistisisme dalam Islam (Jakarta: Bulan Bintang, t.t.), p. 38. 
The agenda must be immediately executed with the cooperation between Muslim organizations and the government or other institutions. Because, basically, the purpose of the mission is to improve the life of mankind on earth and the hereafter. If they continue to feel depressed state, distress, and suffered duping; how could worship emphasis on serenity and humility can they run.

As we know that Islam is a perfect religion, because every human activity has been arranged by Allah swt. Through faith in His namely Islam. So that any activity undertaken to contain a blessing and a benefit for the life of the world and in the hereafter, for any activity intended to gain His pleasure, then it certainly will be the value of worship. Including economic activities carried out properly in accordance Shari'ah also worth worship. Besides, Muslims in Indonesia can not escape the fact the emergence of new communities in the life perkonomian namely the Asean Economic Community (AEC), so it must set up your self to deal with it. There are four things that will be the focus of the AEC in 2015, namely:

First, countries in Southeast Asia will be used as a unified region market and production base. With the creation of the unity of the market and production base will make the flow of goods, services, investment, capital in large numbers, and a skilled workforce being no obstacle from one country to another country in Southeast Asia.

Second, ASEAN Economic Community will be established as an economic region with a high level of competition, which requires a policy that includes competition policy, consumer protection, Intellectual Property Rights (IPR), taxation, and E-Commerce.

Third, the AEC will serve as the region has equitable economic development, with priority on Small and Medium Enterprises (SMEs). Competitiveness and dynamism of 
SMEs will be improved by facilitating their access to the latest information, market conditions, the development of human resources in terms of capacity building, finance, and technology.

Fourth, ASEAN Economic Community will be fully integrated to the global economy. By building a system to improve coordination of the member states. In addition, there will be increased participation of countries in Southeast Asia in the global supply chain through the development of a package of technical assistance to countries less developed ASEAN members. This is done to improve the capabilities and productivity of the industry so that not only enhancing their participation in a regional scale, but also led the initiative to globally integrated.

Free trade MEA should evoke and develop the characters and typical of Indonesia in the eyes of the world, especially Asean, where Indonesia has a population of Moslem world will be a benchmark establishment of an economic community Asean-based Islamic, certainly in the free trade MEA will prioritize how to transact based Islamic law. To achieve the objectives that characterize the Muslims would require a variety of tricks and strategies in practice, highlighting excellence and Islamic economic principles of honest and promoting the principle of consensual, then it will form the character of the people in the face of free trade economic community Asean, one of which is to develop products based on the principle of Islamic economics as Islamic banking, as well as other matters are managed based on the principle of Islam. Besides, it also develops the quality of the people to get ready for the MEA.

There are several approaches propaganda that can be done in improving the quality of people that approach the cultural ${ }^{20}$, educational approaches and psychological approaches.

${ }^{20}$ Sjahudi Siradj, Ilmu Dakwah Suatu Tinjanan Methodologis (Surabaya: IAIN Sunan Ampel, t.t.), p. 29-33. 
Approaches focused on mad'u for example by using areas of social life. Da'wah approach this model is more emphasis on socio-political approach, the approach of the socio-cultural, socio-economic approach and socio-psychological approach. To improve the quality of people through da'wah to do with structural or political approach.

Based on the description of the above approach to da'wah, which is centered approach mad'u and preacherscentered approach. In this regard will be focused on an approach centered on mad' $^{\prime} u$ because he will be the target of a change in their quality. Not only at the level of understanding, but also change the attitudes and behavior of mad' $^{\prime} u^{21}$

After selecting the type of approach, then the next step is determining which sided strategy as planning a series of activities designed to achieve a certain da'wah. There are several strategies that can be done that preaching: ${ }^{22}$

a. Strategy sentimental (al-manhaj al-'atifi)

This strategy is focused da'wah aspect of the heart and stir your feelings and inner mad' $u$ (target da'wah). Advise impressive, calling with tenderness, or provide satisfactory service are some of the methods developed from this strategy. These methods correspond to the conditions mad'u marginalized (marginal) and is considered weak, such as women, children of people who are still common, converts (faith is weak), the poor, orphans and so on. This sentimental strategy applied by the Prophet Muhammad to face the polytheists in Mecca.

b. Rational strategies (al-manhaj al-'aqli)

Rational strategy is a strategy of propaganda by some method that focuses on the mind. This strategy encourage

${ }^{21}$ Aziz, Imu Dakwah, p. 349.

${ }^{22}$ Muhammad Abu al-Fath al-Bayanuni, Madkhal ila Ilm ad-Da'wah (Beirut: Mu'assasah ar-Risalah, 1993), p. 204-209. 
mad'u to think, reflect, and take heed. The use of the laws of logic, discussion, or the appearance of historical examples and evidence are several methods of rational strategies. In this case the al-Qur'an encouraging the use of rational strategies with some of the terminology, among others: tafakkur, tazakkur, nazar, ta'ammul, itibar, tadabbur, and istibsar. Tafakkur is using the mind to achieve it and think about it.

c. Sensory strategies (al-manhaj al-bissi)

Finally propaganda strategy that is referred to as a strategy experimentation or scientific strategies that da'wah-oriented system senses and sticking to the results of research and experiments. Application of this strategy include the religious practices and exemplary.

Each chosen strategy requires careful planning. In the institutional strategy, for example, strategic planning at least contain a SWOT analysis which is a continuation of the strength, weakness, opportunities and threats that are owned or facing the organization of da'wah. Advantages and disadvantages are more internal da'wah strategy associated with the presence of the specified strategy.

Additionally da'wah strategy requires precise adjustments, by far the weaknesses and threats and to increase the benefits and opportunities. This adjustment patterns by M. Natsir ${ }^{23}$ called da'wah bi al-hikmah (da'wah wisely) with a few things:

a. Wise in identifying groups;

b. Wise in choosing when to speak and when to be silent;

c. Wise in thinking to make contact and find a meeting point as a starting point to move forward systematically;

d. Wise does not release sibgah;

e. Wise to select and prepare the right word;

${ }^{23}$ M. Natsir, Fiqhud Dakwah (Semarang: Ramadhani, 1984), p. 161. 
f. Wise in parting ways;

g. Wise with exemplary good sense (uswab hasanah and lisan al-bal).

In addition, in developing quality people can also be done in various ways including: The method used would follow the example of the steps taken by the Prophet in the form of noble character. Namely: (a) Change the mindsets of mankind, must rely to trust and follow God's commands in the broadest sense. (b) Provide concrete examples, practice, and get used to follow the commands of the Lord are in his relationship to be good to fellow human beings, and the universe is the universe. Examples and habituation noble character, for example he has shown in the case of marriage, being kind to family, friends and others, buying and selling, to hang out with communities of different religions, in diplomacy, war, and lead the state. (c) Conducting the selection process, accommodation and reintegration with the values and customs ("urf) as appropriate and relevant. (d) Make changes, modifications, diffusion, cancellation, and elimination of moral past that is not good in a way evolutif. (e) Based on the concept of human nature as creatures loving kindness (ethics), beauty (aesthetics), and truth (logic). (f) Provide reward and funishment wisely against any person who violates the teachings of the Lord.

By using propaganda strategy is expected to increase the quality of the people, so that it can face the ASEAN Economic Community (AEC) armed with the ability and moral qualities possessed.

\section{Conclusion}

AEC (Asean Economic Community) is a single market that is approved by the ASEAN countries in the past decade. AEC is the acronym for the ASEAN Economic Community. AEC is done in order to increase the competitiveness of ASEAN as well as China and India could compete to attract 
.Mubasyaroh

foreign investment. Foreign investment in the region is needed to boost employment which in turn will improve the welfare of the population in ASEAN countries.

All the people in Indonesia must be ready to face the AEC not to mention the Muslims, so they need to prepare themselves by developing quality people through da'wah. With good quality, then Muslims will easily and boldly confront the existence of the AEC. 


\section{REFERENCES}

Ahmad, Amrullah. Dakwah Islam dan Perubahan Sosial: Suatu Kerangka Pendekatan dan Permasalahan. Yogyakarta: Bina Putra, 1993.

Aziz, Ali. Ilmu Dakwah. Jakarta: Prenada Media Group, 2009. al-Bayanuni, Muhammad Abu al-Fath. Madkhal ila Tlm adDa'wah. Beirut: Mu'assasah ar-Risalah, 1993.

Hasymi, A. Dustur Dakwah Menurut al-Qur'an. Jakarta: Bulan Bintang, 1997.

Hilali, Majdi. Mengubah Hal-hal Negatif dalam Diri. Jakarta: Samara Publishing, 2008.

Ismail, A. Ilyas. Paradigmma Dakwah Sayyid Quthub Rekonstruksi Pemikiran Dakwah Harakah. Jakarta: Penamadani, 2006.

Kementerian Pendidikan Nasional Dirjen Pendidikan Dasar Direktorat Pembinaan Sekolah Menengah Pertama. Panduan Pendidikan Karakter di Sekolah Menengah Pertama. Jakarta: Diknas, 2011.

Mahfudz, Syekh Ali. Hidayah al-Mursyidin ila Turuq al-Wa'az wa al-Khitabah. Beirut: Dar-al Ma'rifah, t.t.

Majid, Abdul and Dian Andayani. Pendidikan Karakter Perspektif Islam. Bandung: Remaja Rosdakarya, 2012.

al-Munawwir, Warson. Kamus Arab-Indonesia. Surabaya: Pustaka Progresif, 1997.

Nasution, Harun. Falsafah dan Mistisisme dalam Islam. Jakarta: Bulan Bintang, t.t.

Nata, Abudin. Akblak Tasawuf dan Karakter Mulia. Jakarta: RajaGrafindo Persada, 2015.

Natsir, M. Fiqhud Dakwah. Semarang: Ramadhani, 1984.

Rahmat, Jalaluddin. Psikologi Agama Sebuah Pengantar. Bandung: Mizan Pustaka, 2005. 
.Mubasyaroh

Severin, J. Warner and James W. Tankard Jr. Communication Theories: Origins, Methods, and Uses in the Media (Teori Komunikasi). Jakarta: Prenada Media, 2005.

Siradj, Sjahudi. Ilmu Dakwah Suatu Tinjauan Metodologis. Surabaya: IAIN Sunan Ampel, t.t.

Sulistiyani, Ambar Teguh. Kemitraan dan Model-model Pemberdayaan. Yogyakarta: Gava Media, 2004.

Syukir, Asmuni. Dasar-dasar Strategi Dakwah Islam. Surabaya: alIkhlas, 1993.

Syukriah, Ana. "Peningkatan Eksistensi UMKM Melalui Comparative Advantage dalam Rangka Menghadapi MEA 2015 di Temanggung", Universitas Negeri Semarang, 2013.

Zaidan, Abdul Karim. Ushul ad-Da'wah. Beirut: Mu'asasah arRisalah, 1993. 